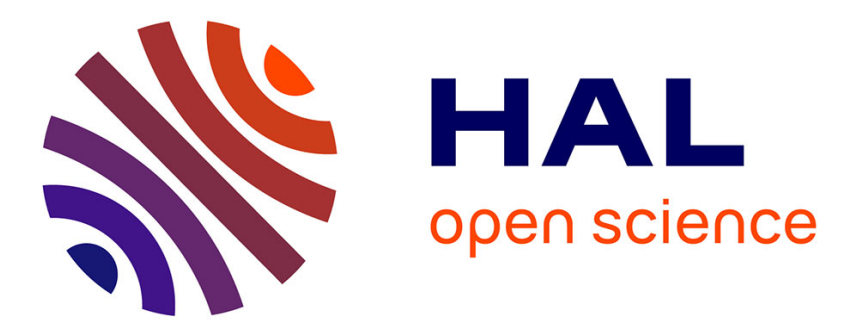

\title{
Heteroleptic lead(II)-halide complexes supported by a bulky iminoanilide ligand
}

Clément Bellini, Jean-François Carpentier, Vincent Dorcet, Anca Silvestru, Yann Sarazin

\section{- To cite this version:}

Clément Bellini, Jean-François Carpentier, Vincent Dorcet, Anca Silvestru, Yann Sarazin. Heteroleptic lead(II)-halide complexes supported by a bulky iminoanilide ligand. Main Group Metal Chemistry, 2017, 40 (3-4), pp.2515 - 2515. 10.1515/mgmc-2017-0033 . hal-01612237

\section{HAL Id: hal-01612237 https://hal.science/hal-01612237}

Submitted on 6 Oct 2017

HAL is a multi-disciplinary open access archive for the deposit and dissemination of scientific research documents, whether they are published or not. The documents may come from teaching and research institutions in France or abroad, or from public or private research centers.
L'archive ouverte pluridisciplinaire $\mathbf{H A L}$, est destinée au dépôt et à la diffusion de documents scientifiques de niveau recherche, publiés ou non, émanant des établissements d'enseignement et de recherche français ou étrangers, des laboratoires publics ou privés. 


\section{Heteroleptic lead(II)-halide complexes supported by a bulky iminoanilide ligand}

Clément Bellini, Jean-François Carpentier, Vincent Dorcet, Anca Silvestru and Yann Sarazin*

Corresponding author: Yann Sarazin, Université de Rennes 1, CNRS, Institut des Sciences Chimiques de Rennes, UMR 6226, Campus de Beaulieu, 35042 Rennes Cedex France, e-mail: yann.sarazin@univ-rennes1.fr

Clément Bellini, Jean-François Carpentier and Vincent Dorcet: Université de Rennes 1, CNRS, Institut des Sciences Chimiques de Rennes, UMR 6226, Campus de Beaulieu, 35042 Rennes Cedex France

Anca Silvestru, Faculty of Chemistry and Chemical Engineering, Babes-Bolyai University, 11 Arany Janos, 400028 Cluj-Napoca, Romania, e-mail: ancas@chem.ubbcluj.ro 


\begin{abstract}
The lead(II) chloride $\left[\left\{\mathrm{N}^{\wedge} \mathrm{N}^{i \mathrm{iP}}\right\} \mathrm{PbCl}\right](\mathbf{1})$, where $\left\{\mathrm{N}^{\wedge} \mathrm{N}\right\}^{-}$is a bulky, monoanionic, bidentate iminoanilide ligand, was synthesised by salt metathesis between $\left[\left\{\mathrm{N}^{\wedge} \mathrm{N}^{\mathrm{iPr}}\right\} \mathrm{Li}\right]$ and $\mathrm{PbCl}_{2}$. The complex was characterised by X-ray diffraction crystallography and ${ }^{207} \mathrm{~Pb} \mathrm{NMR}$ spectroscopy. It exists in the molecular solid-state as a monometallic three-coordinate species, with two independent, similar but not identical molecules per asymmetric unit. The differences between the first coordination sphere of $\mathbf{1}$ and that of Fulton's structurally related $\beta$-diketiminato complex $\left[\left\{\mathrm{N}^{\wedge} \mathrm{N}^{\mathrm{iPr}}\right\} \mathrm{PbCl}\right]$ are illustrated. The synthesis of $\mathbf{1}$ offers a convenient handle in the still underdeveloped organometallic and inorganic chemistry of lead(II), as exemplified by the synthesis of the alkyl complex $\left[\left\{\mathrm{N}^{\wedge} \mathrm{N}^{\mathrm{iPr}}\right\} \mathrm{PbCH}\left(\mathrm{CH}_{3}\right)_{2}\right](\mathbf{3})$. The iodo complex $\left[\left\{\mathrm{N}^{\wedge} \mathrm{N}^{\mathrm{iPr}}\right\} \mathrm{PbI}\right](\mathbf{2})$ was also synthesised but, unlike $\mathbf{1}$, it showed limited stability in solution.
\end{abstract}

Keywords: lead(II) chloride; iminoanilide; coordination sphere; lead(II) alkyl 


\section{Introduction}

Lead has been extensively used in industry, as an anti-knock additive in petrol and in metal piping, until its high toxicity has been judged prohibitive. The coordination chemistry of lead has on the other hand attracted little attention. It is only in the past two decades that bulky ancillary ligands have yielded low-coordinate lead(II) complexes, and that their reactivity have been explored. Until then, lead(II) complexes had been plagued by light sensitivity and by a propensity to decompose and form insoluble lead(0) during uncontrolled redox processes.

Major advances in lead(II) coordination chemistry were achieved with monodentate terphenyl and bidentate $\beta$-diketiminato ligands, and a number of remarkable two- and threecoordinate complexes were structurally characterised. Terphenyls have for instance yielded the encumbered two-coordinate $\left[\mathrm{Pb}\left\{\mathrm{Ar}^{\prime}\right\}_{2}\right]$ (Simons et al., 1997) and [\{ $\left.\left.\mathrm{Ar}^{\prime}\right\} \mathrm{PbSi}\left(\mathrm{SiMe}_{3}\right)_{3}\right](\mathrm{Klett}$ et al., 1999) where $\mathrm{Ar}{ }^{\prime}=\mathrm{C}_{6} \mathrm{H}_{3} \mathrm{Mes}_{2}-2,6$, the halo-bridged dimers $\left[\left\{\mathrm{Ar}{ }^{\prime}\right\} \mathrm{Pb}(\mu-\mathrm{Br})\right]_{2}(\mathrm{Pu}$ et al., 2000) and $\left[\left\{\mathrm{Ar}{ }^{\prime}\right\} \mathrm{Pb}(\mu-\mathrm{I})\right]_{2}$ (Filippou et al., 2004) where $\mathrm{Ar} "{ }^{\prime}=\mathrm{C}_{6} \mathrm{H}_{3}$ Trip $_{2}-2,6$, and the two-coordinate organolead(II) compounds [ $\left.\left\{\mathrm{Ar}{ }^{\prime} "\right\} \mathrm{PbR}\right]$ for $\mathrm{R}=\mathrm{Me},{ }^{\mathrm{t}} \mathrm{Bu}$ or $\mathrm{Ph}$ (Pu et al., 2000). More recently, the groups of Fulton and Roesky have reported on monometallic lead(II) compounds stabilised by ubiquitous $\beta$-diketiminates. The halides $\left[\left\{\mathrm{BDI}^{\mathrm{iPr}}\right\} \mathrm{PbX}\right]$, where $\mathrm{X}=\mathrm{Cl}, \mathrm{Br}$ or I, were disclosed in 2007 (Chen et al., 2007); the compounds were obtained by salt metathesis between $\mathrm{PbX}_{2}$ and $\left[\left\{\mathrm{BDI}^{\mathrm{iPr}}\right\} \mathrm{Li}\right]$. The missing halide in this family (Figure 1$),\left[\left\{\mathrm{BDI}^{\mathrm{iPr}}\right\} \mathrm{PbF}\right]$, was later reported by Roesky and co-workers, upon fluorination of $\left[\left\{\mathrm{BDI}^{\mathrm{iPr}}\right\} \mathrm{PbNMe}_{2}\right]$ with pentafluoropyridine (Jana et al., 2011). A variety of terminal aryloxides (Fulton et al., 2007), alkoxides (Tam et al., 2009), phosphides (Yao et al., 2007; Tam et al., 2012), amides and anilides (Harris et al., 2014) and

alkyl (Jana et al., 2009; Taylor et al., 2015) mononuclear compounds [ $\left.\left\{\mathrm{BDI}^{\mathrm{iPr}}\right\} \mathrm{PbX}\right]$ were also synthesised by salt metathesis reactions, most of them from the chloro complex $\left[\left\{\mathrm{BDI}^{\mathrm{iPr}}\right\} \mathrm{PbCl}\right]$. 
Fulton and co-workers also revealed a rare case of lead(II) cation, $\left[\left\{\mathrm{BDI}^{\mathrm{iPr}}\right\} \mathrm{Pb}\right]^{+}$. $\left[\mathrm{B}\left(\mathrm{C}_{6} \mathrm{~F}_{5}\right)_{4}\right]^{-}$ (Taylor et al., 2011). Their preparation of $\left[\left\{\mathrm{BDI}^{\mathrm{Me}}\right\} \mathrm{PbCl}\right]$ and $\left[\left\{\mathrm{BDI}^{\mathrm{H}}\right\} \mathrm{PbCl}\right]$ showed that bulky isopropyl groups in ortho positions of the $\beta$-diketiminate, as in $\left\{\mathrm{BDI}^{\mathrm{iPr}}\right\}^{-}$, were not mandatory to obtain stable, monometallic lead(II) compounds (Tam et al., 2015). The role of mononuclear chloro complexes, in particular as precursors for salt metathesis reactions, was prominent in these studies. Finally, a case of Cl-bridged aminoanilido lead(II) dimer was reported (Vaňkátová et al, 2011), where the distances between each metal centre and the two bridging chlorides exhibited a large difference, 2.620(2) and 3.167(2) $\AA$.

\section{[Insert Figure 1 here]}

We have used the iminoanilide $\left\{\mathrm{N}^{\wedge} \mathrm{N}^{\mathrm{iPr}}\right\}^{-}$to synthesise a variety of alkaline-earth complexes (Figure 1). Our interest in this ligand framework stems in particular from its structural similarities with the versatile $\left\{\mathrm{BDI}^{\mathrm{iPr}}\right\}^{-}$, although the more rigid nature of the backbone in $\left\{\mathrm{N}^{\wedge} \mathrm{N}^{\mathrm{iPr}}\right\}^{-}$imparts original properties to this ligand (Liu et al., 2012; Liu et al., 2013). We have also developed aminophenolato (Wang et al., 2014) and organochalchogenolato (Pop et al., 2014) lead(II) complexes as well as simple alkoxides devoid of bulky ancillary ligands (Wang et al., 2015), and shown that they were competent molecular catalysts. As part of our ongoing programme in main group chemistry, we report here on the synthesis and molecular solid-state structure of the chloro complex $\left[\left\{\mathrm{N}^{\wedge} \mathrm{N}^{\mathrm{iPr}}\right\} \mathrm{PbCl}\right]$, and on its derivatisation to $\left[\left\{\mathrm{N}^{\wedge} \mathrm{N}^{\mathrm{iPr}}\right\} \mathrm{Pb}{ }^{\mathrm{i}} \mathrm{Pr}\right]$.

\section{Results and Discussion}

The room temperature treatment in THF of anhydrous $\mathrm{PbCl}_{2}$ with an equimolar amount of $\left\{\mathrm{N}^{\wedge} \mathrm{N}^{\mathrm{iPr}}\right\} \mathrm{K}$, freshly prepared by deprotonation of the proligand with potassium hydride, afforded the chloro complex $\left[\left\{\mathrm{N}^{\wedge} \mathrm{N}^{\mathrm{iPr}}\right\} \mathrm{PbCl}\right](\mathbf{1})$ (Scheme 1). The product was isolated in $62 \%$ yield as 
analytically pure orange crystals upon recrystallisation from a pentane solution. The identity of $\mathbf{1}$ was established on the basis of NMR spectroscopy and X-ray diffraction crystallography, and its purity was corroborated by combustion analysis. Pure, microcrystalline $\left[\left\{\mathrm{N}^{\wedge} \mathrm{N}^{\mathrm{iPr}}\right\} \mathrm{PbI}\right](2)$ was obtained in similar fashion in $31 \%$ non-optimised yield upon reaction of $\mathrm{PbI}_{2}$ and $\left\{\mathrm{N}^{\wedge} \mathrm{N}^{\mathrm{iPr}}\right\} \mathrm{K}$. Both compounds are readily soluble in common non-protic organic solvents, including aliphatic hydrocarbons.

\section{[Insert Scheme 1 here]}

The NMR spectroscopic data for the two complexes were recorded in benzene- $d_{6}$. The ${ }^{1} \mathrm{H}$ NMR spectrum of complex 1 display a diagnostic singlet at $8.21 \mathrm{ppm}$ for the imine Ar- $\mathrm{CH}=\mathrm{N}$ hydrogen, with a distinctive ${ }^{3} J_{\mathrm{HPb}}$ coupling constant of $56 \mathrm{~Hz}$ consistent with the binding $N_{\text {imine }}$ to the metal. The corresponding resonance appears at $8.11 \mathrm{ppm}$ in the ${ }^{1} \mathrm{H}$ spectrum of complex $\mathbf{2}$, which exhibits broad resonances at $298 \mathrm{~K}$ testifying to fluxional processes in solution. In the ${ }^{13} \mathrm{C}\left\{{ }^{1} \mathrm{H}\right\}$ NMR spectra, the resonances for $\mathrm{Ar}-\mathrm{CH}=\mathrm{N}$ carbons atoms are detected at 167.17 and $168.22 \mathrm{ppm}$ for $\mathbf{1}$ and $\mathbf{2}$, respectively. The ${ }^{207} \mathrm{~Pb}$ NMR spectra were recorded for the two complexes. No resonance could be detected for $\mathbf{2}$, perhaps because the complex starts decomposing to unidentifiable species in solution within 3-4 hours, or perhaps owing to strong coupling to iodide $\left(I=5 / 2\right.$ for $\left.{ }^{127} \mathrm{I}\right)$, broadening the resonance that could not be distinguished from the baseline. We note that similarly, the ${ }^{207} \mathrm{~Pb}$ resonance for $\left[\left\{\mathrm{BDI}^{\mathrm{iPr}}\right\} \mathrm{PbI}\right]$ has to our knowledge been reported neither in the seminal paper (Chen et al., 2007) nor later. On the other hand, the ${ }^{207} \mathrm{~Pb}$ resonance for $\mathbf{1}$ was detected at $+1317 \mathrm{ppm}$, i.e. in the region diagnostic of threecoordinate $\beta$-diketiminato lead(II) chlorides: compare for instance with the resonances for $\left[\left\{\mathrm{BDI}^{\mathrm{Pr}}\right\} \mathrm{PbCl}\right]\left(+1413 \mathrm{ppm}\right.$; Jana et al., 2009), $\left[\left\{\mathrm{BDI}^{\mathrm{Me}}\right\} \mathrm{PbCl}\right]$ and $\left[\left\{\mathrm{BDI}^{\mathrm{H}}\right\} \mathrm{PbCl}\right](+1227$ and +1388 ppm; Tam et al., 2015). The resonance for the Cl-bridged aminoanilide [\{(2- 
$\left.\left.\left.\mathrm{Me}_{2} \mathrm{NCH}_{2}\right) \mathrm{C}_{6} \mathrm{H}_{4} \mathrm{~N}\left(\mathrm{SiMe}_{3}\right)\right\} \mathrm{Pb}(\mu-\mathrm{Cl})\right]_{2}$ was somewhat deshielded (+1816 ppm), although this may result from the different nature of the ancillary ligand rather than from the four-coordinate environment of the metal centres in this dinuclear complex (Vaňkátová et al, 2011).

The molecular solid-state structure of the chloro complex 1 was established by single crystal X-ray diffraction analysis. The asymmetric unit contains two similar, but not identical, molecules of $\left[\left\{\mathrm{N}^{\wedge} \mathrm{N}^{\mathrm{iPr}}\right\} \mathrm{PbCl}\right], \mathbf{1 a}$ and $\mathbf{1 b}$. The distance of the lead atom to the mean planes defined by the $\mathrm{N}_{\text {anilide }}-\mathrm{C}-\mathrm{C}-\mathrm{C}=\mathrm{N}_{\text {imine, }}$, that is, 0.53 (for 1a) and $0.32 \AA$ (for $\mathbf{1 b}$ ), is the main difference between the two independent components. The structure of 1a is depicted in Figure 2, and only the geometric parameters for this component are discussed in detail. A summary of interatomic distances and angles data for $\mathbf{1 a}$ and $\mathbf{1 b}$, showing their close similarities, is collated in Table 1.

[Insert Figure 2 here]

The chloride $\mathrm{Cl1}$ sits in endo conformation, i.e. roughly perpendicular to the $\mathrm{N}_{\text {anilide }}-\mathrm{C}-\mathrm{C}-\mathrm{C}=\mathrm{N}_{\text {imine }}$ plane (aka N1-C2-C7-C8-N9) as seen for other $\beta$-diketiminato Pb(II)-halides. The Pb1-Cl1 bond length $(2.5912(19) \AA)$ in 1a compares well with those measured in Fulton's $\beta$-diketiminates $\left[\left\{\mathrm{BDI}^{\mathrm{iPr}}\right\} \mathrm{PbCl}\right](2.5653(7) \AA)$ and [\{BDI $\left.\left.{ }^{\mathrm{Me}}\right\} \mathrm{PbCl}\right](2.5757(11) \AA)$, and it is much shorter than in the polymeric $\left[\left\{\mathrm{BDI}^{\mathrm{H}}\right\} \mathrm{PbCl}\right](2.8081(11)$ and $2.9928(11) \AA$ ) (Tam et al., 2015). The $\mathrm{Pb} 1-\mathrm{N} 1$ distance is expectedly shorter for the negatively charged $\mathrm{N}_{\text {amide }}$ atom (2.246(6) $\AA$ ) than the Pb1N9 distance $(2.336(6) \AA)$ to the neutral $\mathrm{N}_{\text {imine }}$ atom. By comparison, the two pertaining $\mathrm{Pb}-\mathrm{N}$ bonds are commensurate in $\beta$-diketiminato complexes, e.g. in $\left[\left\{\mathrm{BDI}^{\mathrm{iPr}}\right\} \mathrm{PbCl}\right](2.290(2)$ and 2.280(2) $\AA$ ), in $\left[\left\{\mathrm{BDI}^{\mathrm{H}}\right\} \mathrm{PbCl}\right](2.279(3)$ and $2.285(4) \AA)$, or in $\left[\left\{\mathrm{BDI}^{\mathrm{Me}}\right\} \mathrm{PbCl}\right](2.288(3)$ and 2.306(3) ̊) (Tam et al., 2015). On the other hand, the pertaining Pb-N bonds were much longer (2.459(3) and 2.426(3) $\AA$ ) in the dimeric complex $[\{\mathrm{L}\} \mathrm{Pb}]_{2}$ incorporating the dianionic $\mathrm{N}-\{2-([4-$ 
N-ethylthiose-micarbazone]methyl)phenyl $\}$-p-toluene-sulfonamide ligand $\{\mathrm{L}\}^{-}$and featuring four-coordinate lead atoms (Pedrigo et al., 2008). The geometry about N1 and N9 is trigonal planar, with the sum of angles reaching respectively 359.9 and $359.5^{\circ}$. The geometry about the lead(II) atom is pyramidal, the sum of angles amounting to $260.2^{\circ}$. Note however that the angles show a certain deviation from the ideal value of $90^{\circ}$ expected for three-coordinate lead(II) centres with purely $6 s^{2}$ unpaired electrons, thus showing some contribution of the empty $p_{z}$ orbital to electronic lone pair in 1a. The degree of pyramidalisation (DoP) of the metal in 1a, defined by $\left.\operatorname{DoP}=\left[360-\sum_{i=1}^{3} \theta(i)\right] / 0.9\right]$ where $\theta(\mathrm{i})$ are the angles around lead(II) (Maksić and Kovačević, 1999), comes to $111 \%$, exceeding by about $10-15 \%$ those found in most chloro lead(II) $\beta$-diketiminates. However, both values are very similar to those measured in $\left[\left\{\mathrm{BDI}^{\mathrm{H}}\right\} \mathrm{PbCl}\right]\left(\right.$ sum of angles $\left.=261^{\circ}, \mathrm{DoP}=110 \%\right)($ Tam et al., 2015).

[Insert table 1 here]

The existence of two distinct molecules, $\mathbf{1 a}$ and $\mathbf{1 b}$, in the asymmetric unit of the molecular structure of $\mathbf{1}$, can be tentatively linked to the presence of close molecules $\mathbf{1 a}$ ' and $\mathbf{1 b}$ ' in the crystal lattice (but in adjacent asymmetric units). Hence, the lead atoms, $\mathrm{Pb} 1$ in $\mathbf{1 a}$ and $\mathrm{Pb} 2$ in $\mathbf{1 b}$, are located at short range of the chlorides $\mathrm{Cl1}^{\prime}$ and $\mathrm{Cl} 2$ ' from the respective neighbouring symmetry-related molecules $\mathbf{1} \mathbf{a}^{\prime}$ and $\mathbf{1} \mathbf{b}^{\prime}$. Due to packing forces, the different distances $\mathrm{Pb} 2{ }^{\prime} \mathrm{C} 12$ ' (3.353 $\AA$, see Figure 3$)$ and $\mathrm{Pb} 1 \cdots \mathrm{C} 11$ ' (3.428 $\left.\mathrm{A}\right)$, may hence impact the respective positions of the lead atoms $\mathrm{Pb} 1$ and $\mathrm{Pb} 2$ with respect to the mean NCCCN plane. Note that these two distances are too long for a $\mathrm{Pb}-\mathrm{Cl}$ bond. For instance, the $\mathrm{Pb}-\mathrm{Cl}$ bond lengths in the polymeric $\left[\left\{\mathrm{BDI}^{\mathrm{H}}\right\} \mathrm{PbCl}\right], 2.8081(11)$ and $2.9928(11) \AA$ (Tam et al., 2015), were much shorter than $\mathrm{Pb} 1 \cdots \mathrm{C} 11^{\prime}$ and $\mathrm{Pb} 2 \cdots \mathrm{Cl} 2{ }^{\prime}$ distances in 1a and $\mathbf{1 b}$. On the other hand, in

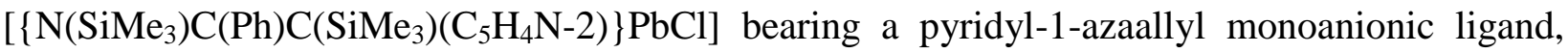


the $\mathrm{Pb}-\mathrm{Cl}$ bond lengths were in the range $2.599(2)-2.641(2) \AA$, whereas there was no interaction between the metal atoms and chlorides situated at a greater distance, 3.086(2)-3.173(2) Å (Leung et al., 2005).

[Insert Figure 3 here]

In an attempt to prepare a lead(II) alkyl, 1 was reacted with an equimolar amount of ${ }^{i} \mathrm{PrMgBr}$. The orange microcrystalline $\left[\left\{\mathrm{N}^{\wedge} \mathrm{N}^{\mathrm{iPr}}\right\} \mathrm{PbCH}\left(\mathrm{CH}_{3}\right)_{2}(\mathrm{THF})\right]$ (3) was isolated from pentane, but X-ray quality crystals eluded us. The identity of $\mathbf{3}$ was authenticated by its NMR data recorded in benzene- $d_{6}$. The ${ }^{1} \mathrm{H}$ NMR spectrum given in Figure 4 shows the formation of the targeted product. The high field heptet at $0.01 \mathrm{ppm}$ was assigned to $[\mathrm{Pb}]-\mathrm{CH}\left(\mathrm{CH}_{3}\right)_{2}$. In the ${ }^{13} \mathrm{C}\left\{{ }^{1} \mathrm{H}\right\}$ NMR spectrum, the metal-bound isopropyl generates resonances at $8.77 \mathrm{ppm}$ for $\mathrm{PbCH}\left(\mathrm{CH}_{3}\right)_{2}$ and $25.34 \mathrm{ppm}$ for $\mathrm{PbCH}\left(\mathrm{CH}_{3}\right)_{2}$. The presence of one molecule of THF that could not be removed in vacuo was detected in the ${ }^{1} \mathrm{H}$ and ${ }^{13} \mathrm{C}\left\{{ }^{1} \mathrm{H}\right\}$ NMR spectra, with resonances at $\delta_{1 \mathrm{H}}=3.49$ and $1.14 \mathrm{ppm}$ and at $\delta_{13 \mathrm{C}}=69.66$ and $24.82 \mathrm{ppm}$. These chemical shifts, different from those of free THF in benzene- $d_{6}$, suggest binding of THF to the metal. This would result in a 20electron complex if the imine remained coordinated. The $C H=\mathrm{N}$ imine remains intact in $\mathbf{3}$, as corroborated by a singlet at $7.95 \mathrm{ppm}$ in the ${ }^{1} \mathrm{H}$ NMR spectrum and a downfield resonance at $171.48 \mathrm{ppm}$ in the ${ }^{13} \mathrm{C}\left\{{ }^{1} \mathrm{H}\right\}$ spectrum.

[Insert Figure 4 here]

\section{Conclusion}

The iminoanilido complex $\left[\left\{\mathrm{N}^{\wedge} \mathrm{N}^{\mathrm{iPr}}\right\} \mathrm{PbCl}\right](\mathbf{1})$, a useful addition to the limited number of soluble three-coordinate lead(II) chlorides, has been synthesised and structurally characterised. This complex a priori opens access upon derivatisation to a larger panel of other lead(II) complexes, as 
exemplified by the preparation of a lead(II)-alkyl complex $\left[\left\{\mathrm{N}^{\wedge} \mathrm{N}^{\mathrm{iPr}}\right\} \mathrm{PbCH}\left(\mathrm{CH}_{3}\right)_{2}\right]$ (3); further examples can be anticipated from the extensive work in this area by the group of Fulton. The coordination sphere of $\mathbf{1}$ shows noticeable differences with that of the analogous $\beta$-diketiminato complex $\left[\left\{\mathrm{BDI}^{\mathrm{iPr}}\right\} \mathrm{PbCl}\right]$; a summary of the coordination spheres in the iminoanilido $\left[\left\{\mathrm{N}^{\wedge} \mathrm{N}^{\mathrm{iPr}}\right\} \mathrm{PbCl}\right](\mathbf{1})$ and Fulton's congeneric $\beta$-diketiminato $\left[\left\{\mathrm{BDI}^{\mathrm{iPr}}\right\} \mathrm{PbCl}\right]($ Chen et al., 2007) is provided in Figure 5; only the most pertinent bond lengths and angles are given. In conjunction with the data obtained earlier with large alkaline earths (Liu et al., 2012; Liu et al., 2013), the results disclosed here illustrate that subtle differences of coordination patterns are to be expected when one or the other of the two structurally related ligand platforms $\left\{\mathrm{N}^{\wedge} \mathrm{N}^{\mathrm{iPr}}\right\}^{-}$and $\left\{\mathrm{BDI}{ }^{\mathrm{iPr}}\right\}^{-}$are used. This may bear substantial implications for applicative purposes, for instance in molecular catalysis where control of the first coordination sphere about the central metal takes a prominent role.

\section{[Insert Figure 5 here]}

\section{Experimental Section}

\section{General procedures}

All manipulations were performed under inert atmosphere using standard Schlenk techniques or in a dry, solvent-free glove-box (Jacomex; $\mathrm{O}_{2}<1$ ppm, $\mathrm{H}_{2} \mathrm{O}<5$ ppm) for catalyst loading. Solvents (THF, $\mathrm{Et}_{2} \mathrm{O}, \mathrm{CH}_{2} \mathrm{Cl}_{2}$, pentane and toluene) were purified and dried (water contents below $8 \mathrm{ppm}$ ) over alumina columns (MBraun SPS). THF was further distilled under argon from sodium/benzophenone ketyl. All deuterated solvents (Eurisotop, Saclay, France) were stored in sealed ampoules over activated $3 \AA$ molecular sieves and were thoroughly degassed by several freeze-thaw-vacuum cycles. $\mathrm{PbCl}_{2}$ and $\mathrm{PbI}_{2}$ were purchased from Strem and used as received. 
${ }^{\mathrm{i}} \mathrm{PrMgBr}\left(1.0 \mathrm{M}\right.$ solution in THF) was bought from Aldrich. $\left\{\mathrm{N}^{\wedge} \mathrm{N}^{\mathrm{iPr}}\right\} \mathrm{H}$ (Hayes et al., 2003) was synthesised according to literature procedures.

NMR spectra were recorded on Bruker AM-400 and AM-500 spectrometers. All ${ }^{1} \mathrm{H}$ and ${ }^{13} \mathrm{C}\left\{{ }^{1} \mathrm{H}\right\}$ chemicals shifts were determined using residual signals of the deuterated solvents and were calibrated $v s$. $\mathrm{SiMe}_{4}$. Assignment of the signals was carried out using $1 \mathrm{D}\left({ }^{1} \mathrm{H},{ }^{13} \mathrm{C}\left\{{ }^{1} \mathrm{H}\right\}\right)$ and 2D (COSY, HMBC, HMQC) NMR experiments. ${ }^{207} \mathrm{~Pb}$ NMR spectra were referenced externally against a solution of $\left[\mathrm{Pb}\left[\mathrm{N}\left(\mathrm{SiMe}_{3}\right)_{2}\right]_{2}\right]$ in benzene- $d_{6}(\delta 207 \mathrm{~Pb}=+4916 \mathrm{ppm})$.

Elemental analyses were performed on a Carlo Erba 1108 Elemental Analyser instrument at the London Metropolitan University by Stephen Boyer and were the average of two independent measurements.

$\left[\left\{\mathbf{N}^{\wedge} \mathbf{N}^{\mathrm{iPr}}\right\} \mathbf{K}\right]:\left\{\mathrm{N}^{\wedge} \mathrm{N}^{\mathrm{iPr}}\right\} \mathrm{H}(1.00 \mathrm{~g}, 2.27 \mathrm{mmol})$ was dissolved in toluene $(50 \mathrm{~mL}) . \mathrm{KH}(0.10 \mathrm{~g}, 2.50$ mmol) was added in fractions using a bent finger. The reaction mixture was heated at $80{ }^{\circ} \mathrm{C}$ overnight. The solution was then cooled to room temperature, filtered to remove insoluble materials, and the solvent was pumped off under vacuum. Following washing with pentane $(3 \times 5$ $\mathrm{mL}),\left\{\mathrm{N}^{\wedge} \mathrm{N}^{\mathrm{iPr}}\right\} \mathrm{K}$ was isolated as an orange powder $(1.0 \mathrm{~g}, 92 \%)$. The spectroscopic and analytical data for this product matched those described in the literature (Kloek and Goldberg, 2007).

[\{ $\left.\left.\mathbf{N}^{\wedge} \mathbf{N}^{\mathrm{iPr}}\right\} \mathbf{P b C l}\right] \mathbf{( 1 )}$ : Anhydrous $\mathrm{PbCl}_{2}(0.41 \mathrm{~g}, 1.47 \mathrm{mmol})$ was suspended in THF (10 mL). $\left[\left\{\mathrm{N}^{\wedge} \mathrm{N}^{\mathrm{iPr}}\right\} \mathrm{K}\right](0.92 \mathrm{~g}, 1.47 \mathrm{mmol})$ was dissolved in $\mathrm{THF}(10 \mathrm{~mL})$ and the solution was added dropwise with a cannula to the solution of $\mathrm{PbCl}_{2}$ at room temperature. The reaction mixture was stirred for $12 \mathrm{~h}$, during which a white precipitate gradually appeared. The precipitate was eliminated by filtration and the solvent was pumped off under vacuum. Complex $\mathbf{1}$ was extracted with pentane $(3 \times 5 \mathrm{~mL})$ and isolated as orange crystals $(0.63 \mathrm{~g}, 62 \%)$ by crystallisation at -27 ${ }^{\circ} \mathrm{C}$. Single crystals suitable for X-ray diffraction studies were selected from this batch. ${ }^{1} \mathrm{H}$ NMR 
(benzene- $\left.d_{6}, 400.1 \mathrm{MHz}, 298 \mathrm{~K}\right): \delta 8.21\left(\mathrm{t}, 1 \mathrm{H}, \mathrm{CH}=\mathrm{N},{ }^{3} J_{\mathrm{HPb}}=56 \mathrm{~Hz}\right), 7.31\left(\mathrm{~d},{ }^{3} J_{\mathrm{HH}}=7.4 \mathrm{~Hz}\right.$, $3 \mathrm{H}$, arom- $H), 7.13(\mathrm{~m}, 1 \mathrm{H}$, arom- $H), 7.02(\mathrm{~m}, 4 \mathrm{H}$, arom- $H), 6.41(\mathrm{~m}, 1 \mathrm{H}$, arom- $H), 6.24(\mathrm{~m}, 1 \mathrm{H}$, arom- $H$ ), 3.93 (hept, $\left.{ }^{3} J_{\mathrm{HH}}=6.4 \mathrm{~Hz}, 2 \mathrm{H}, \mathrm{CH}\left(\mathrm{CH}_{3}\right)_{2}\right), 3.27$ (hept, $\left.{ }^{3} J_{\mathrm{HH}}=6.2 \mathrm{~Hz}, 1 \mathrm{H}, \mathrm{CH}\left(\mathrm{CH}_{3}\right)_{2}\right)$, 3.05 (hept, ${ }^{3} \mathrm{~J}_{\mathrm{HH}}=6.2 \mathrm{~Hz}, 1 \mathrm{H}, \mathrm{CH}\left(\mathrm{CH}_{3}\right)_{2}$ ), 1.50 (overlapping m, 6H, $\mathrm{CH}\left(\mathrm{CH}_{3}\right)_{2}$ ), 1.15 (overlapping m, 12H, $\mathrm{CH}\left(\mathrm{CH}_{3}\right)_{2}$ ), 0.99 (br, $\left.6 \mathrm{H}, \mathrm{CH}\left(\mathrm{CH}_{3}\right)_{2}\right)$ ppm. ${ }^{13} \mathrm{C}\left\{{ }^{1} \mathrm{H}\right\}$ NMR (benzene- $d_{6}$, $125.8 \mathrm{MHz}, 298 \mathrm{~K}): \delta 167.17(\mathrm{CH}=\mathrm{N}), 157.93\left(\mathrm{~N}=\mathrm{CH}-i-C_{6} \mathrm{H}_{4}\right), 152.00\left(\mathrm{ArN}-i-C_{6} \mathrm{H}_{3}\right), 151.47$ $\left(\mathrm{CH}=\mathrm{N}-i-C_{6} \mathrm{H}_{3}\right), 147.86\left(\mathrm{~N}-i-C_{6} \mathrm{H}_{4}\right), 141.85\left(\mathrm{ArN}-o-C_{6} \mathrm{H}_{3}\right), 139.5\left(\mathrm{~N}=\mathrm{CH}-o-C_{6} \mathrm{H}_{4}\right), 132.36(\mathrm{~N}-o-$ $\left.C_{6} \mathrm{H}_{4}\right), 124.35\left(\mathrm{CH}=\mathrm{N}-o-C_{6} \mathrm{H}_{3}\right), 123.90\left(\mathrm{ArN}-m-C_{6} \mathrm{H}_{3}\right), 123.14\left(\mathrm{CH}=\mathrm{N}-m-C_{6} \mathrm{H}_{3}\right), 121.21(\mathrm{~N}=\mathrm{CH}-$ $\left.m-C_{6} \mathrm{H}_{4}\right), \quad 117.23 \quad\left(\mathrm{CH}=\mathrm{N}-p-C_{6} \mathrm{H}_{3}\right), \quad 116.48 \quad\left(\mathrm{ArN}-p-C_{6} \mathrm{H}_{3}\right), \quad 107.44 \quad\left(\mathrm{~N}=\mathrm{CH}-p-C_{6} \mathrm{H}_{4}\right), \quad 29.01$ $\left(\mathrm{CH}\left(\mathrm{CH}_{3}\right)_{2}\right), 28.59\left(\mathrm{CH}\left(\mathrm{CH}_{3}\right)_{2}\right), 28.13$ (br, $\left.\mathrm{CH}\left(\mathrm{CH}_{3}\right)_{2}\right), 27.83$ (br, $\left.\mathrm{CH}\left(\mathrm{CH}_{3}\right)_{2}\right), 24.83\left(\mathrm{CH}\left(\mathrm{CH}_{3}\right)_{2}\right)$, 24.45 (br, $\left.\mathrm{CH}\left(\mathrm{CH}_{3}\right)_{2}\right), 24.30$ (br, $\left.\mathrm{CH}\left(\mathrm{CH}_{3}\right)_{2}\right), 23.79\left(\mathrm{CH}\left(\mathrm{CH}_{3}\right)_{2}\right)$ ppm. ${ }^{207} \mathrm{~Pb}$ NMR (benzene- $d_{6}$, 83.97 MHz, $298 \mathrm{~K}): \delta=1317 \mathrm{ppm}$. Elemental analysis for $\mathrm{C}_{31} \mathrm{H}_{39} \mathrm{ClN}_{2} \mathrm{~Pb}\left(682.32\right.$ g.mol $\left.{ }^{-1}\right)$ : theoretical, C 54.57\%, H 5.76\%, N 4.11\%; found C 54.6\%, H 5.9\%, N $3.9 \%$.

[\{ $\left.\left.\mathbf{N}^{\wedge} \mathbf{N}^{\mathrm{iPr}}\right\} \mathbf{P b I}\right]$ (2): Anhydrous $\mathrm{PbI}_{2}(0.48 \mathrm{~g}, 1.05 \mathrm{mmol})$ was suspended in THF $(10 \mathrm{~mL})$. $\left\{\mathrm{N}^{\wedge} \mathrm{N}^{\mathrm{iPr}}\right\} \mathrm{K}(0.50 \mathrm{~g}, 1.05 \mathrm{mmol})$ was dissolved in THF $(10 \mathrm{~mL})$ and the solution was added dropwise with a cannula to the solution of $\mathrm{PbI}_{2}$ at room temperature. The reaction mixture was stirred for $12 \mathrm{~h}$, and a white precipitate formed gradually. The precipitate was removed by filtration, and the solvent was pumped off under vacuum. The product was extracted with pentane $(3 \times 5 \mathrm{~mL})$ and isolated as an analytically pure orange solid $(0.25 \mathrm{~g}, 31 \%)$ following precipitation at $-27{ }^{\circ} \mathrm{C}$. Note that the complex started decomposing within ca. 3-4 $\mathrm{h}$ in solution, which precluded the recording of reliable ${ }^{13} \mathrm{C}\left\{{ }^{1} \mathrm{H}\right\}$ NMR data. ${ }^{1} \mathrm{H}$ NMR (benzene- $d_{6}, 400.1 \mathrm{MHz}, 298$ $\mathrm{K}): \delta 8.11(\mathrm{~s}, 1 \mathrm{H}, \mathrm{CH}=\mathrm{N}), 7.22(\mathrm{~m}, 4 \mathrm{H}, \operatorname{arom}-H), 7.13(\mathrm{~m}, 3 \mathrm{H}, \operatorname{arom}-H), 7.08(\mathrm{~m}, 1 \mathrm{H}$, arom $-H)$, $6.41\left(\mathrm{~d},{ }^{3} J_{\mathrm{HH}}=8.8 \mathrm{~Hz}, 1 \mathrm{H}\right.$, arom- $\left.H\right), 6.24\left(\mathrm{t},{ }^{3} J_{\mathrm{HH}}=7.3 \mathrm{~Hz}, 1 \mathrm{H}\right.$, arom- $\left.H\right), 3.97(\mathrm{br}, 2 \mathrm{H}$, 
$\left.\mathrm{CH}\left(\mathrm{CH}_{3}\right)_{2}\right), 3.27$ (br, 1H, $\left.\mathrm{CH}\left(\mathrm{CH}_{3}\right)_{2}\right), 3.11$ (br, $\left.1 \mathrm{H}, \mathrm{CH}\left(\mathrm{CH}_{3}\right)_{2}\right), 1.50$ (br, 6H, $\left.\mathrm{CH}\left(\mathrm{CH}_{3}\right)_{2}\right), 1.19$ (d, $\left.{ }^{3} J_{\mathrm{HH}}=6.9 \mathrm{~Hz}, 12 \mathrm{H}, \mathrm{CH}\left(\mathrm{CH}_{3}\right)_{2}\right), 0.97\left(\mathrm{br}, 6 \mathrm{H}, \mathrm{CH}\left(\mathrm{CH}_{3}\right)_{2}\right) \mathrm{ppm} .{ }^{13} \mathrm{C}\left\{{ }^{1} \mathrm{H}\right\}$ NMR (benzene- $d_{6}, 125.8$ $\mathrm{MHz}, 298 \mathrm{~K}): \delta 168.22(\mathrm{CH}=\mathrm{N}) \mathrm{ppm}$; the recording of other reliable ${ }^{13} \mathrm{C}\left\{{ }^{1} \mathrm{H}\right\}$ NMR data was precluded by the instability of the complex in solution. No resonance could be detected in the ${ }^{207} \mathrm{~Pb} \mathrm{NMR}$ spectrum of this complex. Elemental analysis for $\mathrm{C}_{31} \mathrm{H}_{39} \mathrm{IN}_{2} \mathrm{~Pb}\left(773.77 \mathrm{~g} \cdot \mathrm{mol}^{-1}\right)$ : theoretical, C 48.12\%, H 5.08\%, N 3.62\%; found C 48.2\%, H 5.2\%, N 3.8\%.

$\left[\left\{\mathbf{N}^{\wedge} \mathbf{N}^{\mathrm{iPr}}\right\} \mathbf{P b C H}\left(\mathbf{C H}_{3}\right)_{2} \cdot \mathbf{T H F}\right]$ (3): Compound $\mathbf{1}(0.20 \mathrm{~g}, 0.29 \mathrm{mmol})$ was dissolved in toluene $(10 \mathrm{~mL})$ and cooled to $-80{ }^{\circ} \mathrm{C}$. A $1.0 \mathrm{M}$ solution of ${ }^{\mathrm{i}} \mathrm{PrMgBr}$ in $\mathrm{THF}(0.29 \mathrm{~mL}, 0.29 \mathrm{mmol})$ was slowly syringed in the reaction mixture, causing a rapid change of colour. The resulting orange solution was stirred for $2 \mathrm{~h}$ at $-80{ }^{\circ} \mathrm{C}$. Toluene was then pumped off under vacuum. The product was extracted with pentane $(3 \times 5 \mathrm{~mL})$ and isolated as an orange microcrystalline material $(50$ $\mathrm{mg}, 25 \%$; yield not optimised) by crystallisation at $-27{ }^{\circ} \mathrm{C} .{ }^{1} \mathrm{H}$ NMR (benzene- $d_{6}, 400.1 \mathrm{MHz}$, $298 \mathrm{~K}): \delta 7.95(\mathrm{~s}, 1 \mathrm{H}, \mathrm{CH}=\mathrm{N}), 7.31(\mathrm{~m}, 3 \mathrm{H}, \operatorname{arom}-H), 7.15(\mathrm{~m}, 3 \mathrm{H}, \operatorname{arom}-H), 6.94\left(\mathrm{~d},{ }^{3} J_{\mathrm{HH}}=6.2\right.$ $\mathrm{Hz}, 1 \mathrm{H}$, arom- $H), 6.83(\mathrm{~m}, 1 \mathrm{H}$, arom- $H), 6.42\left(\mathrm{~d},{ }^{3} J_{\mathrm{HH}}=8.4 \mathrm{~Hz}, 1 \mathrm{H}\right.$, arom- $\left.H\right), 6.25(\mathrm{~m}, 1 \mathrm{H}$, aromH), 3.49 (br, 4H, $\left.\mathrm{OCH}_{2} \mathrm{CH}_{2}\right), 3.37$ (br, 2H, $\left.\mathrm{CH}\left(\mathrm{CH}_{3}\right)_{2}\right), 3.18$ (br, 2H, $\left.\mathrm{CH}\left(\mathrm{CH}_{3}\right)_{2}\right), 1.40-1.05$ (several overlapping m, 30H, $\left.\mathrm{CH}\left(\mathrm{CH}_{3}\right)_{2}\right), 1.14\left(\mathrm{~m}, 4 \mathrm{H}, \mathrm{OCH}_{2} \mathrm{CH}_{2}\right), 0.01$ (hept, ${ }^{3} J_{\mathrm{HH}}=7.8 \mathrm{~Hz}$, $\left.1 \mathrm{H}, \mathrm{PbCH}\left(\mathrm{CH}_{3}\right)_{2}\right)$ ppm. ${ }^{13} \mathrm{C}\left\{{ }^{1} \mathrm{H}\right\}$ NMR (benzene-d $\left.d_{6}, 125.8 \mathrm{MHz}, 298 \mathrm{~K}\right): \delta 171.48(\mathrm{CH}=\mathrm{N})$, $160.83\left(\mathrm{~N}=\mathrm{CH}-i-C_{6} \mathrm{H}_{4}\right), 148.35\left(\mathrm{ArN}-i-C_{6} \mathrm{H}_{3}\right), 146.49\left(\mathrm{CH}=\mathrm{N}-i-C_{6} \mathrm{H}_{3}\right), 144.31\left(\mathrm{~N}-i-C_{6} \mathrm{H}_{4}\right)$, $141.35\left(\mathrm{br}, \mathrm{N}=\mathrm{CH}-p-C_{6} \mathrm{H}_{4}\right), 138.20\left(\mathrm{ArN}-o-C_{6} \mathrm{H}_{3}\right), 133.70\left(\mathrm{~N}=\mathrm{CH}-o-C_{6} \mathrm{H}_{4}\right), 126.54\left(\mathrm{~N}-o-C_{6} \mathrm{H}_{4}\right)$, $125.04\left(\mathrm{CH}=\mathrm{N}-o-C_{6} \mathrm{H}_{3}\right), 124.44\left(\mathrm{br}, \mathrm{ArN}-m-C_{6} \mathrm{H}_{3}\right), 123.95\left(\mathrm{CH}=\mathrm{N}-m-C_{6} \mathrm{H}_{3}\right), 119.12(\mathrm{~N}=\mathrm{CH}-m-$ $\left.C_{6} \mathrm{H}_{4}\right), 116.13\left(\mathrm{CH}=\mathrm{N}-p-C_{6} \mathrm{H}_{3}\right), 112.08\left(\mathrm{ArN}-p-C_{6} \mathrm{H}_{3}\right), 69.66\left(\mathrm{OCH}_{2} \mathrm{CH}_{2}\right), 28.48\left(\mathrm{ArCH}\left(\mathrm{CH}_{3}\right)_{2}\right)$, $28.46\left(\mathrm{ArCH}\left(\mathrm{CH}_{3}\right)_{2}\right), 25.65\left(\mathrm{ArCH}\left(\mathrm{CH}_{3}\right)_{2}\right), 25.50\left(\mathrm{ArCH}\left(\mathrm{CH}_{3}\right)_{2}\right), 25.46\left(\mathrm{ArCH}\left(\mathrm{CH}_{3}\right)_{2}\right), 25.34$ $\left(\mathrm{PbCH}\left(\mathrm{CH}_{3}\right)_{2}\right), 24.82\left(\mathrm{OCH}_{2} \mathrm{CH}_{2}\right), 23.34\left(\mathrm{ArCH}\left(\mathrm{CH}_{3}\right)_{2}\right), 8.77\left(\mathrm{PbCH}\left(\mathrm{CH}_{3}\right)_{2}\right)$ ppm. Elemental 


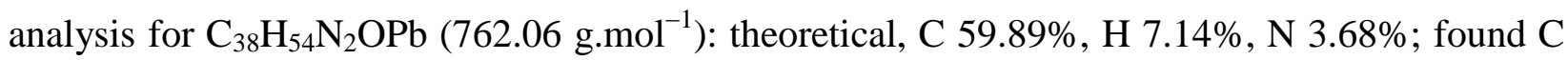
$61.7 \%, \mathrm{H} 7.2 \%, \mathrm{~N} 3.3 \%$.

\section{X-ray diffraction crystallography}

Crystals of $\left[\left\{\mathrm{N}^{\wedge} \mathrm{N}^{\mathrm{iPr}}\right\} \mathrm{PbCl}\right]$ (1) suitable for $\mathrm{X}$-ray diffraction analysis were obtained by recrystallisation of the purified compound. Diffraction data were collected at 150(2) K using a Bruker APEX CCD diffractometer with graphite-monochromated MoK $\alpha$ radiation $(\lambda=0.71073$ $\AA$ ). A combination of $\omega$ and $\Phi$ scans was carried out to obtain at least a unique data set. The crystal structures were solved by direct methods, remaining atoms were located from difference Fourier synthesis followed by full-matrix least-squares refinement based on F2 (programs SIR97 and SHELXL-97) (Sheldrick, 1997a; Sheldrick, 1997b). Carbon- and oxygen-bound hydrogen atoms were placed at calculated positions and forced to ride on the attached atom. All nonhydrogen atoms were refined with anisotropic displacement parameters. The locations of the largest peaks in the final difference Fourier map calculation as well as the magnitude of the residual electron densities were of no chemical significance. Relevant collection and refinement data are collated in Table 1. Crystal data, details of data collection and structure refinement for $\mathbf{1}$ (CCDC $\mathrm{n}^{\circ}$ 1559881) can be obtained free of charge from the Cambridge Crystallographic Data Centre via www.ccdc.cam.ac.uk/data_request/cif.

[Insert table 2 here]

Acknowledgements: C.B. thanks the University of Rennes 1 for a Ph. D. scholarship. 


\section{References}

Chen, M.; Fulton, J. R.; Hitchcock, P. B.; Johnstone, N. C.; Lappert, M. F.; Protchenko, A. V. Synthesis and theoretical studies on rare three-coordinate lead complexes. Dalton Trans. 2007, 2770-2778.

Filippou, A. C.; Weidemann, N.; Schnakenburg, G.; Rohde, H.; Philippopoulos, A. I. Tungstenlead triple bonds: syntheses, structures, and coordination chemistry of the plumbylidyne complexes trans-[X( $\left.\left(\mathrm{PMe}_{3}\right)_{4} \mathrm{~W} \equiv \mathrm{Pb}\left(2,6-\mathrm{Trip}_{2} \mathrm{C}_{6} \mathrm{H}_{3}\right)\right]$. Angew. Chem. Int. Ed. 2004, 43, 65126516.

Fulton, J. R.; Hitchcock, P. B.; Johnstone, N. C.; Tam, E. C. Y. The synthesis of monomeric terminal lead aryloxides: dependence on reagents and conditions. Dalton Trans. 2007, $3360-3362$.

Harris, L. A.-M.; Tam, E. C. Y.; Coles, M. P.; Fulton, J. R. Lead and tin $\beta$-diketiminato amido/anilido complexes: competitive nucleophilic reactivity at the $\beta$-diketiminato $\gamma$ carbon. Dalton Trans. 2014, 43, 13803-13814.

Hayes, P. G.; Welch, G. C.; Emslie, D. J. H.; Noack, C. L.; Piers, W. E.; Parvez, M. A new chelating anilido-imine donor related to $\beta$-diketiminato ligands for stabilization of organoyttrium cations. Organometallics 2003, 22, 1577-1579.

Jana, A.; Pillai Sarish, S.; Roesky, H. W.; Schulzke, C.; Döring, A.; John, M. Facile access of well-defined stable divalent lead compounds with small organic substituents. Organometallics 2009, 28, 2563-2567.

Jana, A.; Pillai Sarish, S.; Roesky, H. W.; Leusser, D.; Objartel, I.; Stalke, D. Pentafluoropyridine as a fluorinating reagent for preparing a hydrocarbon soluble $\beta$-diketiminatolead(II) monofluoride. Chem. Commun. 2011, 47, 5434-5436. 
Klett, J.; Klinkhammer, K. W.; Niemeyer, M. Ligand exchange between arylcopper compounds and bis(hypersilyl)tin or bis(hypersilyl)lead: synthesis and characterization of hypersilylcopper and a stannanediyl complex with a $\mathrm{Cu}-\mathrm{Sn}$ bond. Chem. Eur. J. 1999, 5, 2531-2536.

Kloek, S. M.; Goldberg, K. I. Competitive $\mathrm{C}-\mathrm{H}$ bond activation and $\beta$-hydride elimination at platinum(II). J. Am. Chem. Soc. 2007, 129, 3460-3461.

Leung, W.-P.; So, C.-W.; Wu, Y.-S.; Li, H.-W.; Mak, T. C. W. Synthesis of group 14 metal enamido, alkenyl, imido and alkenyl-amido complexes from a monoanionic pyridyl-1azaallyl ligand. Eur. J. Inorg. Chem. 2005, 513-521.

Liu, B.; Roisnel, T.; Carpentier, J.-F.; Sarazin, Y. When bigger is better: intermolecular hydrofunctionalizations of activated alkenes catalyzed by heteroleptic alkaline earth complexes. Angew. Chem. Int. Ed. 2012, 51, 4943-4946.

Liu, B.; Roisnel, T.; Carpentier, J.-F.; Sarazin, Y. Heteroleptic alkyl and amide iminoanilide alkaline earth and divalent rare earth complexes for the catalysis of hydrophosphination and (cyclo)hydroamination reactions. Chem. Eur. J. 2013, 19, 13445-13462.

Maksić, Z. B.; Kovačević, B. Neutral vs. zwitterionic form of arginine - an ab initio study. $J$. Chem. Soc., Perkin Trans. 2 1999, 2623-2629.

Pedrido, R.; Romero, M. J.; Bermejo, M. R.; González-Noya, A. M.; García-Lema, I.; Zaragoza, G. Metal-catalysed oxidation processes in thiosemicarbazones: new complexes with the ligand N-\{2-([4-n-ethylthiosemicarbazone]methyl)phenyl $\}$-p-toluenesulfonamide. Chem. Eur. J. 2008, 14, 500-512. 
Pop, A.; Wang, L.; Dorcet, V.; Roisnel, T.; Carpentier, J.-F.; Silvestru, A.; Sarazin, Y. On the coordination chemistry of organochalcogenolates $\mathrm{R}^{\mathrm{NMe} 2} \wedge \mathrm{E}^{-}$and $\mathrm{R}^{\mathrm{NMe} 2}{ }^{\wedge} \mathrm{E}^{\wedge} \mathrm{O}^{-}(\mathrm{E}=\mathrm{S}, \mathrm{Se})$ onto lead(II) and lighter divalent tetrel elements. Dalton Trans. 2014, 43, 16459-16474.

Pu, L.; Twamley, B.; Power, P. P. Terphenyl ligand stabilized lead(II) derivatives of simple organic groups: characterization of $\mathrm{Pb}(\mathrm{R}) \mathrm{C}_{6} \mathrm{H}_{3}-2,6-\mathrm{Trip}_{2}(\mathrm{R}=\mathrm{Me}, \mathrm{t}-\mathrm{Bu}$, or $\mathrm{Ph}$; Trip $=$ $\left.\mathrm{C}_{6} \mathrm{H}_{2}-2,4,6-\mathrm{i}-\mathrm{Pr}_{3}\right), \quad\left\{\mathrm{Pb}(\mu-\mathrm{Br}) \mathrm{C}_{6} \mathrm{H}_{3}-2,6-\mathrm{Trip}_{2}\right\}_{2}, \mathrm{py} \cdot \mathrm{Pb}(\mathrm{Br}) \mathrm{C}_{6} \mathrm{H}_{3}-2,6-\mathrm{Trip}_{2}$ (py = pyridine), and the bridged plumbylyne complex $\left[\left\{\mathrm{W}(\mathrm{CO})_{4}\right\}_{2}(\mu-\mathrm{Br})\left(\mu-\mathrm{PbC}_{6} \mathrm{H}_{3}-2,6-\mathrm{Trip}_{2}\right)\right]$. Organometallics 2000, 19, 2874-2881.

Sheldrick, G. M. SHELXS-97, Program for the Determination of Crystal Structures; University of Göttingen: Germany, 1997.

Sheldrick, G. M. SHELXL-97, Program for the Refinement of Crystal Structures; University of Göttingen: Germany, 1997.

Simons, R. S.; Pu, L.; Olmstead, M. M.; Power, P. P. Synthesis and characterization of the monomeric diaryls $\mathrm{M}\left\{\mathrm{C}_{6} \mathrm{H}_{3}-2,6-\mathrm{Mes}_{2}\right\}_{2}\left(\mathrm{M}=\mathrm{Ge}, \mathrm{Sn}\right.$, or $\mathrm{Pb}$; Mes = 2,4,6- $\left.\mathrm{Me}_{3} \mathrm{C}_{6} \mathrm{H}_{2}{ }^{-}\right)$and dimeric aryl-metal chlorides $\left[\mathrm{M}(\mathrm{Cl})\left\{\mathrm{C}_{6} \mathrm{H}_{3}-2,6-\mathrm{Mes}_{2}\right\}\right]_{2}(\mathrm{M}=\mathrm{Ge}$ or $\mathrm{Sn})$. Organometallics 1997, 16, 1920-1925.

Tam, E. C. Y.; Johnstone, N. C.; Ferro, L.; Hitchcock, P. B.; Fulton, J. R. Carbon dioxide activation by “non-nucleophilic” lead alkoxides. Inorg. Chem. 2009, 48, 8971-8976.

Tam, E. C. Y.; Maynard, N. A.; Apperley, D. C.; Smith, J. D.; Coles, M. P.; Fulton, J. R. Group 14 metal terminal phosphides: correlating structure with $\left|J_{\mathrm{MP}}\right|$. Inorg. Chem. 2012, 51, 9403-9415.

Tam, E. C.Y.; Coles, M. P.; Smith, J. D.; Fulton, J. R. The steric influence of $\beta$-diketiminato ligands on the coordination chemistry of lead(II). Polyhedron 2015, 85, 284-294. 
Taylor, M. J.; Saunders, A. J.; Coles, M. P.; Fulton, J. R. Low-coordinate tin and lead cations. Organometallics 2011, 30, 1334-1339.

Taylor, M. J.; Coakley, E. J.; Coles, M. P.; Cox, H.; Fulton, J. R. $\beta$-diketiminato organolead complexes: structures, ${ }^{207} \mathrm{~Pb} \mathrm{NMR}$, and Hammett correlations. Organometallics 2015, 34, $2515-2521$.

Vaňkátová, H.; Broeckaert, L.; De Proft, F.; Olejník, R.; Turek, J.; Padělková, Z.; Růzička, A. Tetrylenes chelated by hybrid amido-amino ligand: derivatives of 2-[(N,Ndimethylamino)methyl]aniline. Inorg. Chem. 2011, 50, 9454-9464.

Wang, L.; Roşca, S.-C.; Poirier, V.; Sinbandhit, S.; Dorcet, V.; Roisnel, T.; Carpentier, J.-F.; Sarazin, Y. Stable divalent germanium, tin and lead amino-(ether)-phenolate monomeric complexes: structural features, inclusion heterobimetallic complexes, and ROP catalysis. Dalton Trans. 2014, 43, 4268-4286.

Wang, L.; Fadlallah, S.; Bellini, C.; Orione, C.; Dorcet, V.; Carpentier, J.-F.; Sarazin, Y. Structurally characterized lead(II) alkoxides as potent ring-opening polymerization catalysts. Organometallics 2015, 34, 1321-1327.

Yao, S.; Block, S.; Brym, M.; Driess, M. A new type of heteroleptic complex of divalent lead and synthesis of the $P$-plumbyleniophosphasilene, $\mathrm{R}_{2} \mathrm{SiLP}=\mathrm{Pb}(\mathrm{L}):(\mathrm{L}=\beta$-diketiminate $)$. Chem. Commun. 2007, 3844-3846. 
Table 1: Comparison of interatomic distances and angles in the two similar but independent molecules $\mathbf{1 a}$ and $\mathbf{1 b}$ in the molecular solid-state structure of $\left[\left\{\mathrm{N}^{\wedge} \mathrm{N}^{\mathrm{iPr}}\right\} \mathrm{Pb}(\mu-\mathrm{Cl})\right](\mathbf{1})$.

\begin{tabular}{|c|c|c|}
\hline Molecule & $\mathbf{1 a}$ & $\overline{1 b}$ \\
\hline $\mathrm{Pb}$ atom & $\mathrm{Pb} 1$ & $\mathrm{~Pb} 2$ \\
\hline \multicolumn{3}{|l|}{ Interatomic distances } \\
\hline $\mathrm{Pb}-\mathrm{Cl}$ & $2.5912(19) \AA$ & $2.574(2) \AA$ \\
\hline $\mathrm{Pb}-\mathrm{N}_{\text {amide }}$ & $2.246(6) \AA$ & $2.249(6) \AA$ \\
\hline $\mathrm{Pb}-\mathrm{N}_{\text {imine }}$ & $2.336(6) \AA$ & $2.361(6) \AA$ \\
\hline $\mathrm{Pb}-\mathrm{NCCCN} \mathrm{N}_{\text {plane }}$ & $0.535 \AA$ & $0.318 \AA$ \\
\hline \multicolumn{3}{|l|}{ Angles } \\
\hline$\angle \mathrm{Cl}-\mathrm{Pb}-\mathrm{N}_{\text {amide }}$ & $94.61(16)^{\circ}$ & $96.17(16)^{\circ}$ \\
\hline$\angle \mathrm{Cl}-\mathrm{Pb}-\mathrm{N}_{\text {imine }}$ & $84.98(15)^{\circ}$ & $85.16(15)^{\circ}$ \\
\hline$\angle \mathrm{N}_{\text {amide }}-\mathrm{Pb}-\mathrm{Pb}-\mathrm{N}_{\text {imine }}$ & $80.60(2)^{\circ}$ & $80.70(2)^{\circ}$ \\
\hline Sum of $\mathrm{Pb}$ angles & $260.2^{\circ}$ & $262.0^{\circ}$ \\
\hline $\operatorname{DoP}(\%)$ & $111 \%$ & $109 \%$ \\
\hline Sum of $\mathrm{N}_{\text {amide }}$ angles & $359.9^{\circ}$ & $359.0^{\circ}$ \\
\hline Sum of $N_{\text {imine }}$ angles & $359.5^{\circ}$ & $359.3^{\circ}$ \\
\hline
\end{tabular}


Table 2: Summary of crystallographic data for $\left[\left\{\mathrm{N}^{\wedge} \mathrm{N}^{\mathrm{iPr}}\right\} \mathrm{Pb}(\mu-\mathrm{Cl})\right]\left(\mathbf{1}, \mathrm{CCDC} \mathrm{n}^{\circ} 1559881\right)$

\section{Formula}

Mol. wt.

Crystal system

Space group

$a(\AA)$

$b(\AA)$

$c(\AA)$

$\alpha\left({ }^{\circ}\right)$

$\beta\left(^{\mathrm{o}}\right)$

$\gamma\left({ }^{\mathrm{o}}\right)$

$\mathrm{V}\left(\AA^{3}\right)$

Z

Density $\left(\right.$ g. $\left.\mathrm{cm}^{-3}\right)$

Abs. coeff., $\left(\mathrm{mm}^{-1}\right)$

$F(000)$

Crystal size, $\mathrm{mm}$

$\theta$ range (deg)

Limiting indices

$R$ (int)

Reflections collected

Reflec. Unique $[I>2 \sigma(I)]$

Completeness to $\theta(\%)$

Data/restraints/param.

Goodness-of-fit

$R_{1}[I>2 \sigma(I)]$ (all data)

wR2 $[I>2 \sigma(I)]$ (all data)

Largest diff. (e. $\mathrm{A}^{-3}$ )

\section{$\mathrm{C}_{62} \mathrm{H}_{78} \mathrm{Cl}_{2} \mathrm{~N}_{4} \mathrm{~Pb}_{2}$}

1364.56

Triclinic

$$
P-1
$$

13.9011(9

14.5332(13)

16.6762(12)

89.727(3)

67.490(3)

69.554(2)

2883.7(4)

2

1.572

5.964

1352

$0.60 \times 0.59 \times 0.58$

2.96 to 27.48

$-18<\mathrm{h}<17$

$-18<\mathrm{k}<18$

$-21<1<21$

0.0628

27332

12970

98.2

12970 / 0 / 629

0.986

$0.0524(0.0820)$

$0.1173(0.1302)$

3.622 and -4.134 

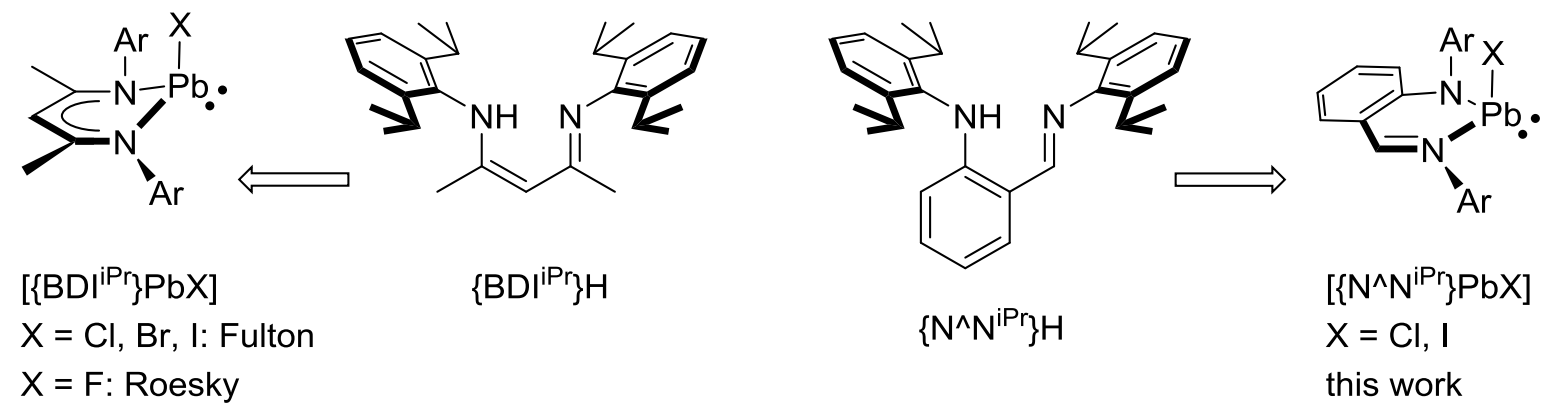

Figure 1: Three-coordinate mononuclear lead(II) halides and their proligands. 


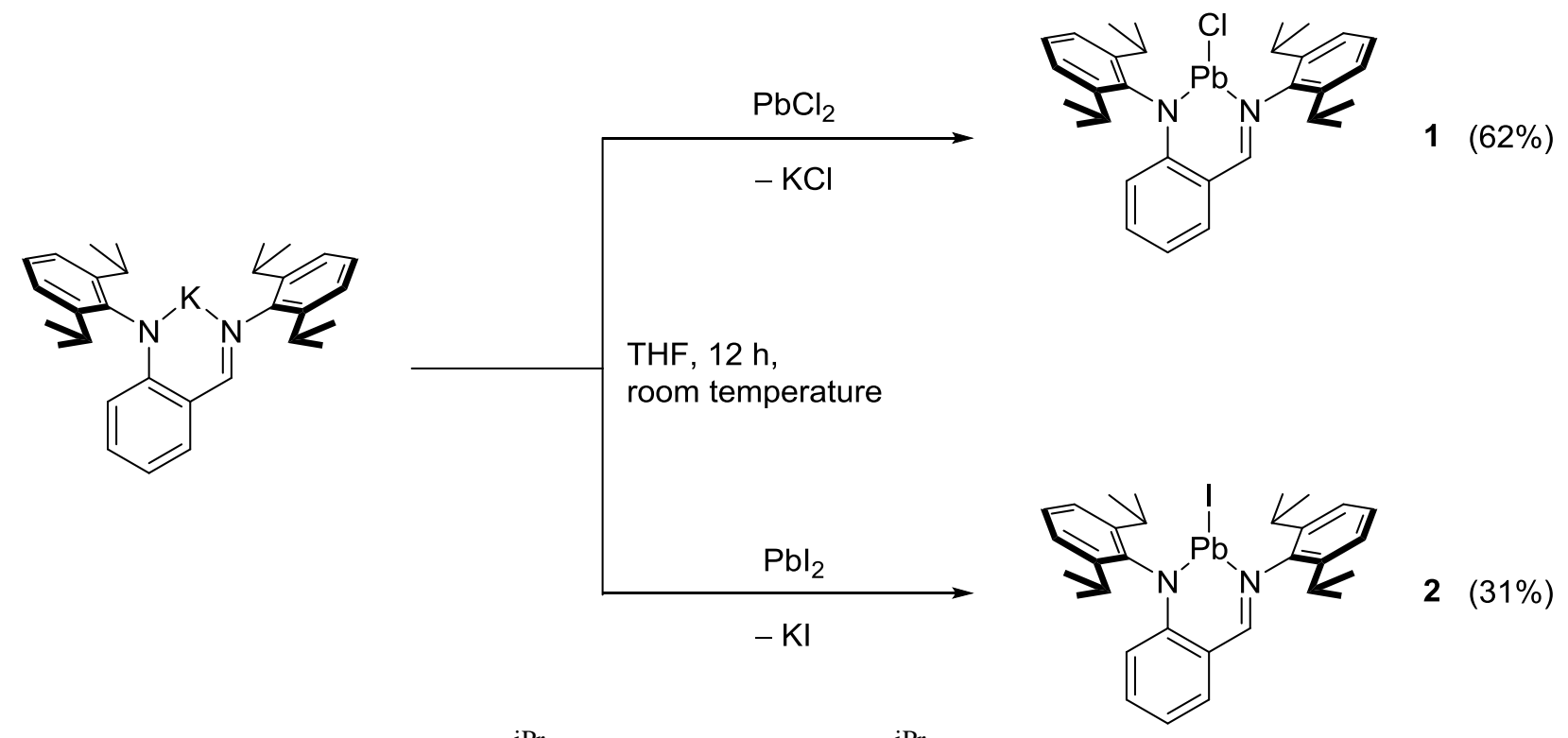

Scheme 1: Syntheses of $\left[\left\{\mathrm{N}^{\wedge} \mathrm{N}^{\mathrm{iPr}}\right\} \mathrm{PbCl}\right](\mathbf{1})$ and $\left[\left\{\mathrm{N}^{\wedge} \mathrm{N}^{\mathrm{iPr}}\right\} \mathrm{PbI}\right](\mathbf{2})$. 


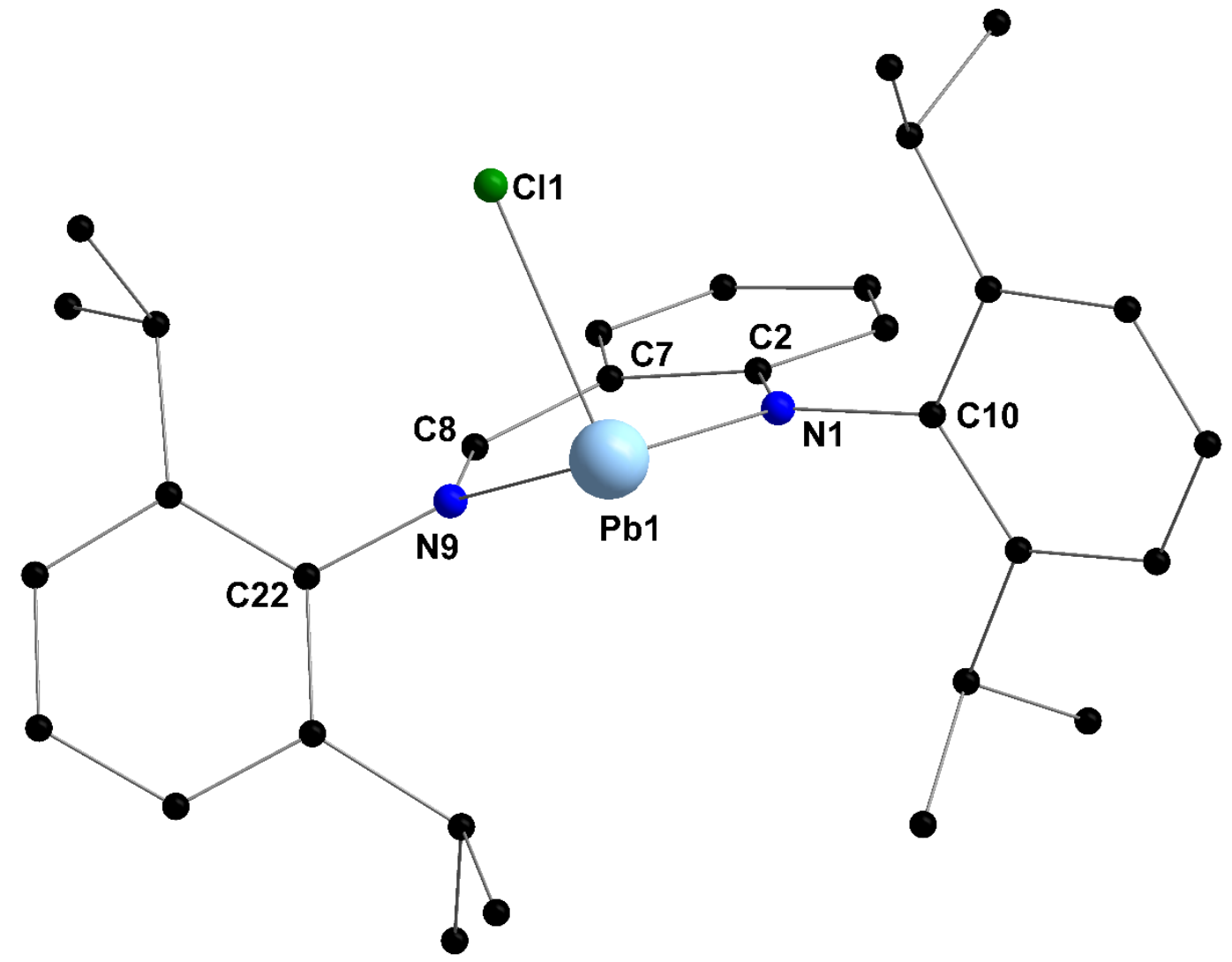

Figure 2: Molecular solid-state structure of one of the two independent components (1a) in $\left[\left\{\mathrm{N}^{\wedge} \mathrm{N}^{\mathrm{iPr}}\right\} \mathrm{PbCl}\right]$ (1). $\mathrm{H}$ atoms are omitted for clarity. Selected interatomic distances $(\AA)$ and angles (deg): Pb1-N1= 2.246(6), Pb1-N9 = 2.336(6), Pb1-Cl1 = 2.5912(19), N1-C2 = 1.357(9), $\mathrm{N} 1-\mathrm{C} 10=1.449(9), \mathrm{C} 2-\mathrm{C} 7=1.434(10), \mathrm{C} 7-\mathrm{C} 8=1.421(9), \mathrm{C} 8-\mathrm{N} 9=1.309(9), \mathrm{N} 9-\mathrm{C} 22=$ 1.434(9); N1-Pb1-N9 = 80.60(2), N1-Pb1-Cl1 = 94.60(16), N9-Pb1-Cl1 = 84.98(15), C2-N1-C10 $=119.50(6), \mathrm{C} 2-\mathrm{N} 1-\mathrm{Pb} 1=131.80(5), \mathrm{C} 10-\mathrm{N} 1-\mathrm{Pb} 1=108.60(4), \mathrm{C} 8-\mathrm{N} 9-\mathrm{C} 22=118.60(6), \mathrm{C} 8-\mathrm{N} 9-$ $\mathrm{Pb} 1=125.20(5), \mathrm{C} 22-\mathrm{N} 9-\mathrm{Pb} 1=115.70(4) . \mathrm{Pb} 1$ sits $0.53 \AA$ above the N1-C2-C7-C8-N9 mean plane. 


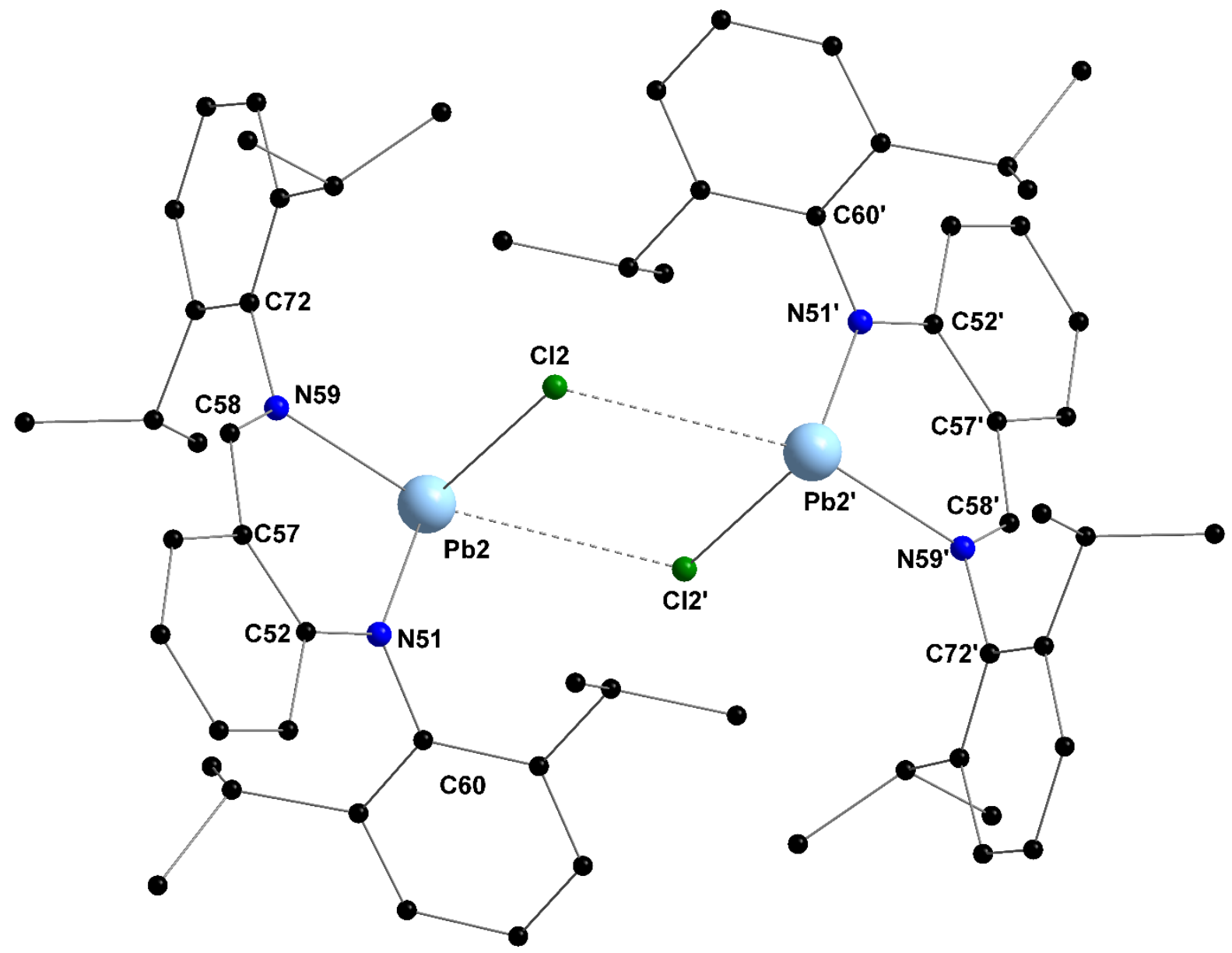

Figure 3: Representation of the molecular solid-state structure of one of the two independent components (1b) in $\left[\left\{\mathrm{N}^{\wedge} \mathrm{N}^{\mathrm{iPr}}\right\} \mathrm{PbCl}\right](\mathbf{1})$, showing the short $\mathrm{Pb} 2 \cdots \mathrm{Cl} 2$ ' and $\mathrm{Pb} 2{ }^{\prime} \cdots \mathrm{Cl} 2$ distances with the symmetry-related 1b'. Selected interatomic distances $(\AA)$ and angles (deg): $\mathrm{Pb} 2-\mathrm{Cl} 2=$ 2.574(2), $\mathrm{Pb} 2-\mathrm{Cl} 2^{\prime}=3.353(2)$; Cl2-Pb2-Cl2' $=78.09(6)$. See table 1 for other key parameters. 


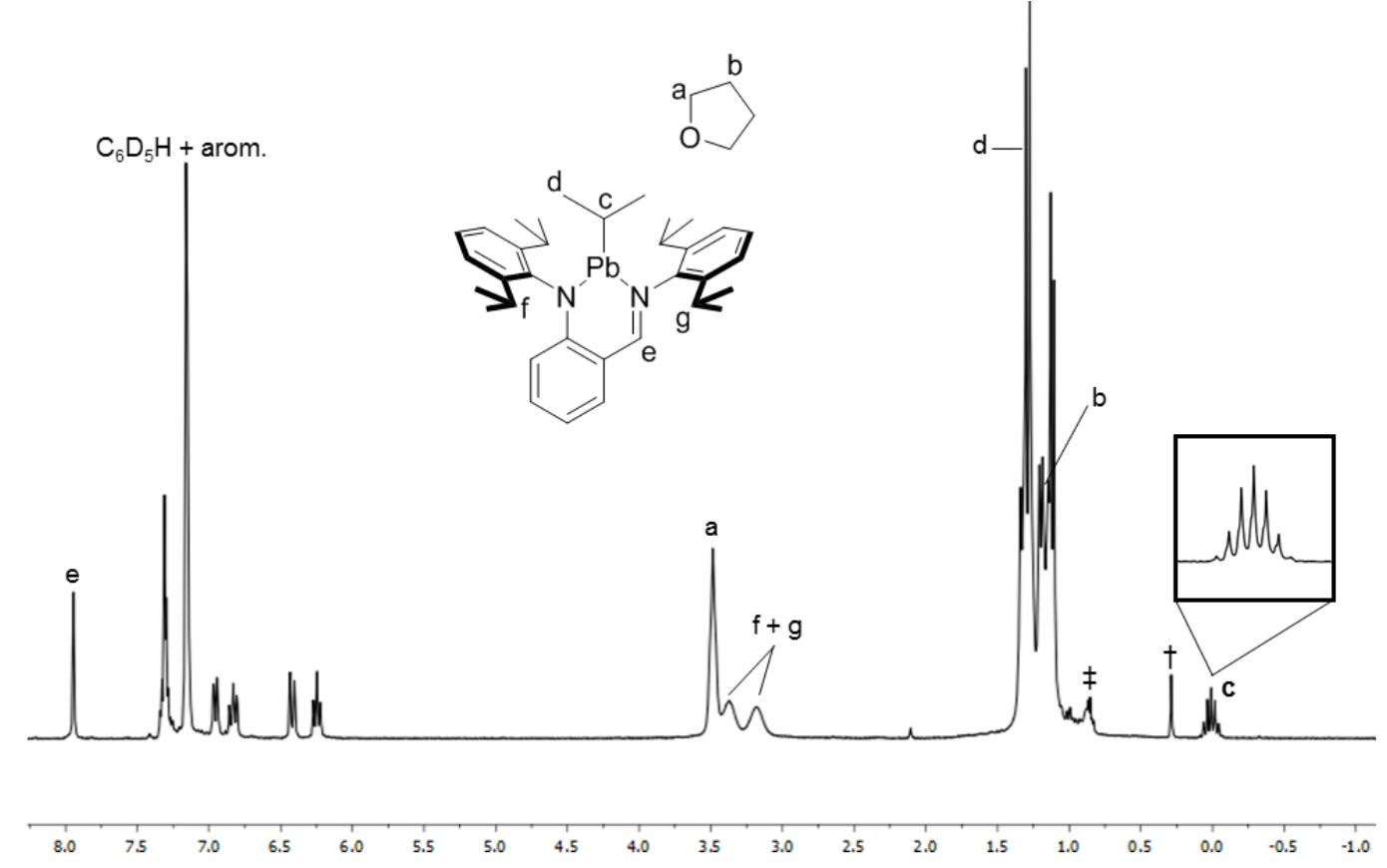

Figure 4: ${ }^{1} \mathrm{H}$ NMR spectrum (benzene- $\left.d_{6}, 400 \mathrm{MHz}, 298 \mathrm{~K}\right)$ of $\left[\left\{\mathrm{N}^{\wedge} \mathrm{N}^{\mathrm{iPr}}\right\} \mathrm{Pb}{ }^{\mathrm{i}} \mathrm{Pr}\right](3) . \dagger=$ silicone grease. $\ddagger=$ residual pentane. 

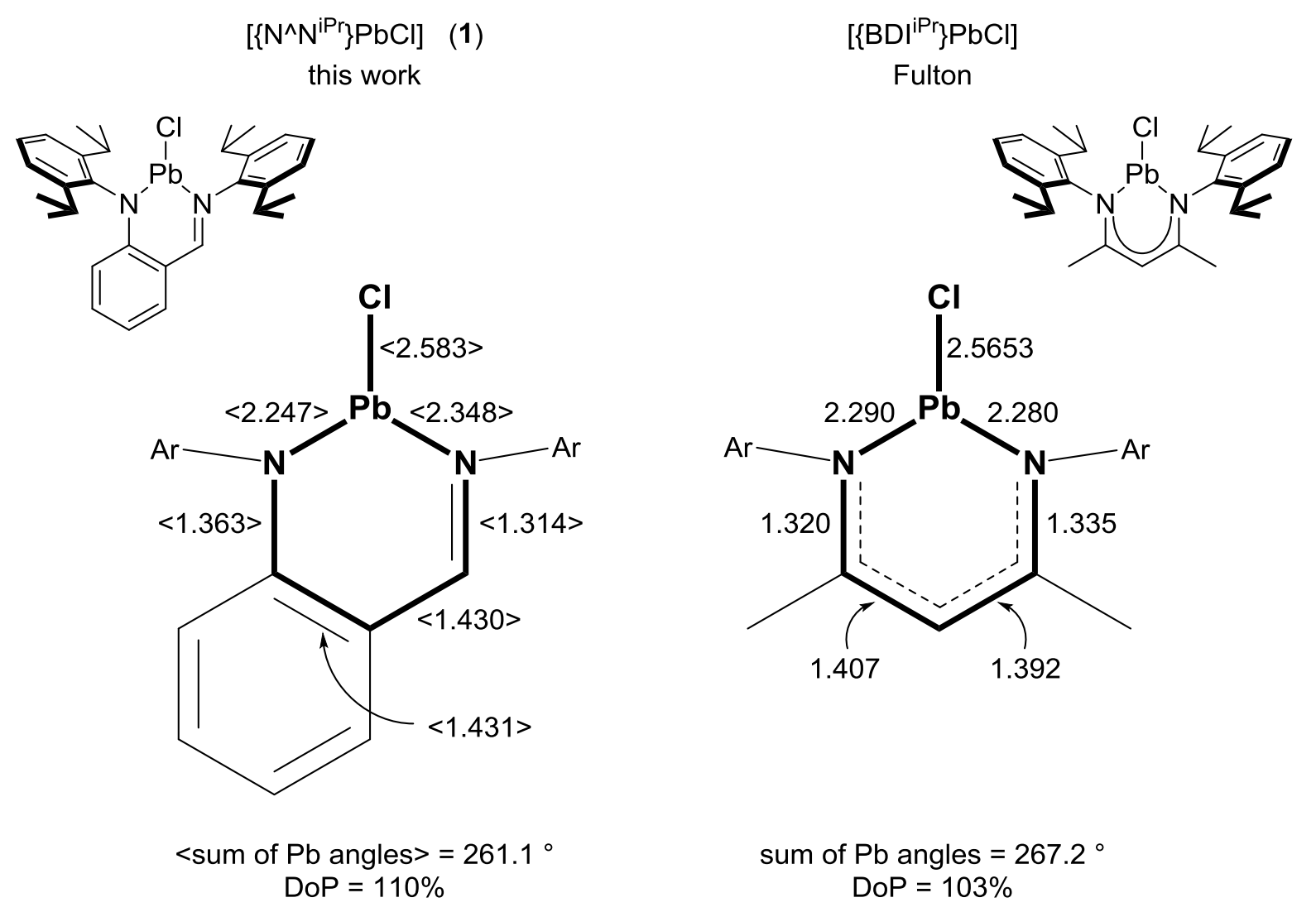

Figure 5: Comparison of interatomic distances (given in $\AA$ ) and angles between $\left[\left\{\mathrm{N}^{\wedge} \mathrm{N}^{\mathrm{iPr}}\right\} \mathrm{PbCl}\right]$ (1) and Fulton's directly related [ $\left.\left\{\mathrm{BDI}^{\mathrm{iPr}}\right\} \mathrm{PbCl}\right]$ (Chen et al., 2007). Average values for the two independent components $\mathbf{1 a}$ and $\mathbf{1 b}$ are given for complex $\mathbf{1}$. 